\title{
REGISTRATION OF LIVE BIRTHS IN MARANHÃO STATE, BRAZIL
}

\author{
Lyanne Polyanne Fernandes Araújo Chaves ${ }^{1}$; Carolina Rocha e Silva ${ }^{1, *}$; Elba Pereira Chaves ${ }^{1,2}$
}

${ }^{1} \mathrm{PhD}$ student for the Biodiversity and Biotechnology Network of the Legal Amazon - Federal University of Maranhão UFMA ${ }^{2}$ Professor of the Department of Zootechnics - State University of Maranhão -UEMA.

*Corresponding author: carolinars@live.com

Received: Aug. 10, 2017 - Accepted: Sep. 22, 2017

DOI: http://dx.doi.org/10.22615/2526-1746-jgm-2.3-6856

\begin{abstract}
Data on births are important, both for demographic and health aspects since they allow the construction of several indicators, such as birth and fecundity rates, and the analysis of the health situation (IBGE, 2009). This way aimed to characterize the live birth numbers in the 217 municipalities in the state of Maranhão through search of secondary data in the public domain, available in Live Births Information System - SINASC, the Ministry of Health for the number of live births in the 217 municipalities of Maranhão state, in the years 2000, 2010 and 2014. From the analysis of the data can be observed that a number of live births in Maranhão is more pronounced in the central Maranhão mesoregion and in some points of the western, eastern and northern mesoregions of the State of Maranhão, with a mean between 101 and 600 births per year. There was a significant variation between the years 2010 and 2000 when comparing births by a period. The data on live births are needed for directing public health policies that come to contribute to social improvement.
\end{abstract}

Key words: birth, Maranhense, population.

\section{REGISTO DE NASCIMENTOS VIVOS NO ESTADO DE MARANHÃO, BRASIL}

RESUMO: Os dados sobre nascimentos são importantes, tanto sob o aspecto demográfico quanto de saúde, por possibilitarem a construção de diversos indicadores, tais como as taxas de natalidade e de fecundidade, e a análise da situação de saúde (IBGE, 2009). Desta forma objetivou-se caracterizar os números os nascidos vivos nos 217 municípios no Estado do Maranhão por meio de busca de dados secundários de domínio público, disponibilizados no Sistema de Informações sobre Nascidos Vivos - SINASC, do Ministério da Saúde referentes a quantidade de nascidos vivos nos 217 municípios do Estado do Maranhão, nos anos de 2000, 2010 e 2014. A partir das análises dos dados pode-se observar que a quantidade de nascidos vivos no Maranhão é mais acentuada na mesorregião centro maranhense e em alguns pontos das mesorregiões oeste, leste e norte do Estado do Maranhão, com em média entre 101 e 600 nascimentos por ano. Obteve-se uma variação significativa entre os anos de 2010 e 2000, ao se comparar os nascimentos por período. Os dados sobre os nascidos vivos são necessários para o direcionamento de políticas públicas em saúde que venha contribuir para melhoria social.

Palavras-chave: nascimento, maranhense, população. 


\section{INTRODUCTION}

Live birth is the complete expulsion from the mother's body, regardless of the duration of pregnancy, of a product of conception which, after separation, breathes or exhibits any other signs of life, such as heartbeat, umbilical cord pulsations or muscles effective movements of voluntary contraction, being or not the umbilical cord cut and being or not the placenta detached (WHO, 1995). The data about births are important, both under demographic and health aspect, by allowing the construction of several indicators, such as birth and fecundity rates, and the analysis of the health situation.

In Brazil, until the early 90s, the birth records were based exclusively on the Civil Registration System. These included only those births that were reported in a registry office, with variable levels of underreporting, according to the country regions. However, in 1990 the Ministry of Health of Brazil deployed the Live Birth Information System (SINASC). The implantation of SINASC occurred gradually among the Federation Units, not being homogeneous throughout the country, being its data only published after 1994 (COSTA and FRIAS, 2009).

With the implementation of SINASC, it has, thus, for the first time, at the municipal, state and national level, not only to provide information on births during the year but also of information on mothers, pregnancy, childbirth, and newborns Thus, it is possible to obtain an epidemiological picture more detailed and spatially disaggregated of maternal and child health conditions (JORGE et al., 2007; COSTA and FRIAS, 2009). Being one of the main components to achieve equity, quality, and humanization of health services, as well as to strengthen social control within the Unified Health System (SUS).

SINASC is based on the data contained in the Declaration of Live Birth (DLB), an official document mandatorily issued by the health unit that the birth occurred (MELLO-JORGE et al., 1993). The information contained in the DLB allows characterizing some aspects of the births extremely useful for the planning of actions in the maternal and child area. Since its implementation, several works have been produced, revealing the profile of the births occurred in several localities of Brazil and the coverage of the system (MAIA, 1997; MELLOJORGE et al., 1993; MELLO-JORGE et al. 1997; SILVA et al., 1997; RODRIGUES et al., 1997; D'ORSI and CARVALHO, 1998; SANTA HELENA and WISBECK, 1998).

In this process, is used demographic, epidemiological, political-social and economic indicators, among others, in order to allow a closer description of the real situation. Some of these indicators are built with statistics related to vital events, to the composition of the population structure.

The knowledge of the number of live births of a State over a period of time is essential, because the same is a component of several indexes and vital coefficients, besides supporting the planning of actions in the health area. This publication aims to characterize the numbers of those born alive in the 217 municipalities that compose the State of Maranhão (Brazil).

\section{MATERIAL AND METHODS}

Maranhão state is located in the Northeast region of Brazil, it is bordered to the north by 
the Atlantic Ocean, to the east by Piauí state, to the west by Pará State, and to the south and southwest by Tocantins state. It has an area of $331,937,450 \mathrm{~km}^{2}$, with 217 municipalities, being the capital São Luís. It has more than $640 \mathrm{~km}$ of coastline, being, therefore, the State with the second largest Brazilian coast, and the one with the greatest ecosystem diversity. The climate is considered tropical, with two distinct seasons, a rainy and other dry and the vegetation is mainly composed of forest, fields, and savannas.

Was carried out the search process for secondary data from the public domain, available in the Live Births Information System (SINASC) of the Ministry of Health. The referred data about a number of live births in the 217 municipalities of Maranhão state, according to SINASC of the years of 2000, 2010 and 2014.

The data were first analyzed using descriptive statistics, being calculated the measures of position (number of states analyzed, sum, maximum, minimum, mean, median) of dispersion (variance and standard deviation), of distribution (coefficient of variation, coefficient of skewness and kurtosis) and hypothesis of normality of the data by the Kolmogorov-Smirnov normality test at $0.01 \%$ probability using the Software Surfer 13. The evaluation of the coefficient of variation (CV) was performed according to GOMES and GARCIA (2002), is considered low $\mathrm{CV}<10 \%$; mean $10<\mathrm{CV}<20 \%$; high $20 \%<C V<30 \%$ and very high $C V>30 \%$.

The municipalities were grouped into scales of numbers of live births ( 1 to 100, 101 to 600,601 to 1,000 and over 1,000 births) to highlight those with higher and lower births.

The Surfer 13 software was used to estimate the variability of the data, in which the isoline map was build of the mean of the referred data for the years 2000, 2010 and 2014. An analysis of ANOVA and Tukey's test were also carried out (BioEstat 5.3) to analyze the live births of the 217 municipalities referring to the studied years.

\section{RESULTS AND DISCUSSION}

A number of live births in Maranhão are more pronounced in the maranhense central mesoregion and in some points in the western, eastern and northern mesoregions of Maranhão state, being the southern mesoregion was the one that presented the lowest birth rate (Figure 1 ).

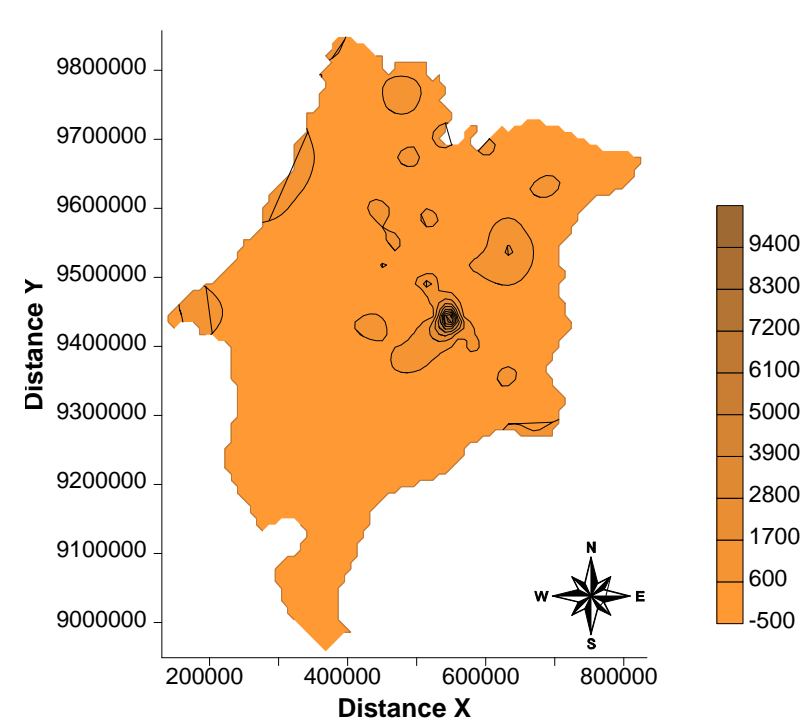

Figure 1. Mean of live births in Maranhão state, from 2000, 2010 and 2014.

When performed a comparative evaluation between the years, were obtained a significant difference between the years of 2010 and $2000(p<0.05)$, but there was no significance between the other periods. This is due to the longer time interval between the years that presented statistical variation, of 
10 years, unlike from the interval of 4 years between the other years (Table 1 ).

According to the Kolmogorov-Smirnov normality test at $0.01 \%$ probability for the mean of the years 2000, 2010 and 2014, the data have a normal log distribution, as evidenced by the high values of the coefficients of skewness (CS $=11.745)$ and kurtosis (CK $=157,028)$, as a coefficient of variation of 215.7 (Table 2).

Table 1. Mean of live births in the municipalities of Maranhão state, in the years 2000, 2010 and 2014.

\begin{tabular}{cc}
\hline Year & Average live births \\
\hline 2000 & 278,28 a b \\
2010 & $541,35 \mathrm{c}$ \\
2014 & $458,44 \mathrm{~b}$ \\
\hline
\end{tabular}

Table 2. Statistical parameters for the mean of the demographic censuses carried out in the years 2000,2010 and 2014

\begin{tabular}{cccccccccccc}
\hline Year & $N$ & Min & Max & Mean & Variance & SD & CV & Skew & Kurtosis & D \\
\hline $\begin{array}{c}\text { 2000, } 2010 \text { and } \\
2014^{*}\end{array}$ & 217 & 56,84 & 12860,66 & 426,02 & 844100,59 & 918,74 & 215,65 & 11,745 & 157,028 & $0.344 \mathrm{Ln}$ \\
\hline
\end{tabular}

* Average years 2000, 2010 and 2014; Min: Minimum; Max: Maximum; SD: standard deviation; CV: Coefficient of variation (\%); D: KolmogorovSmirnov stat (1\%).

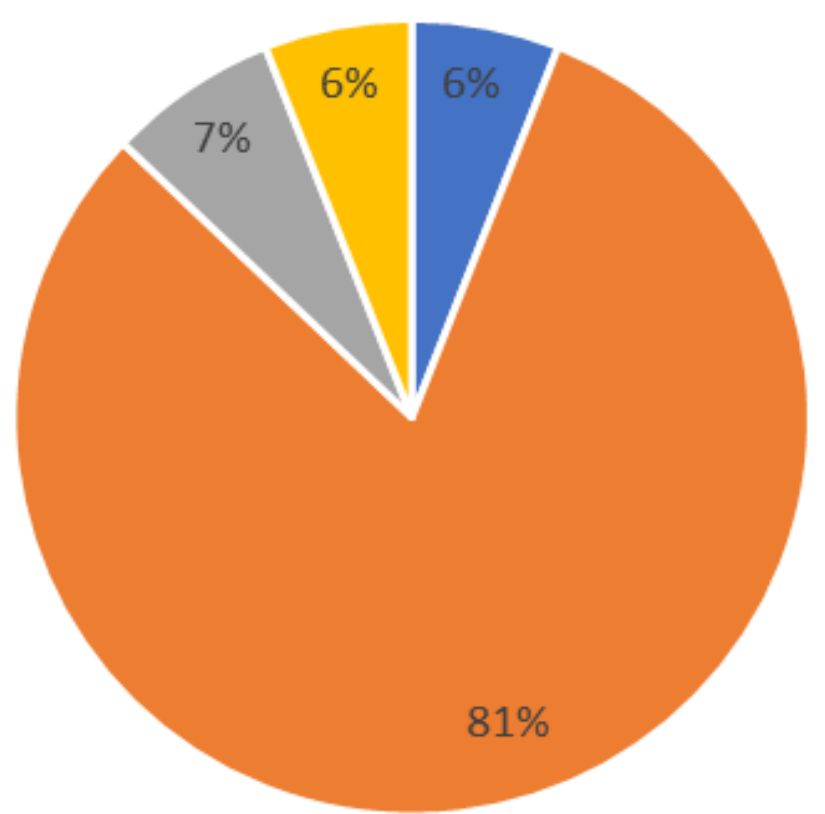

- Between 1 - 100

- Between 101 - 600

- Between 601 - 1000

- Above 1000

Figure 2. Municipalities by mean of live births in 2000, 2010 and 2014 in Maranhão state (Brazil). 
Most cities in Maranhão, 81\%, have means between 101 and 600 births per year, 13\% have between 1 and 100 births, 15\% have between 601 and 1000 births, and 13\% have over 1000 births (Figure 2). Therefore, the population of Maranhão constitutes a mean of not higher than 600 births per year.

The five cities that had the lowest means of live births were Caxias (57), Açailândia (64), Nova Colinas (66), Viana (69) and São José de
Ribamar (75). However, the five cities that have the highest live birth means in the years 2000, 2010 and 2014 were Cidelândia (1618), Carutapera (1918), Timbiras (2018), Igarapé Grande (2836) and São José dos Basílios (12861) (Table 3).

Table 3. Relation of municipalities with the smallest and highest numbers of births in Maranhão State (Brazil).

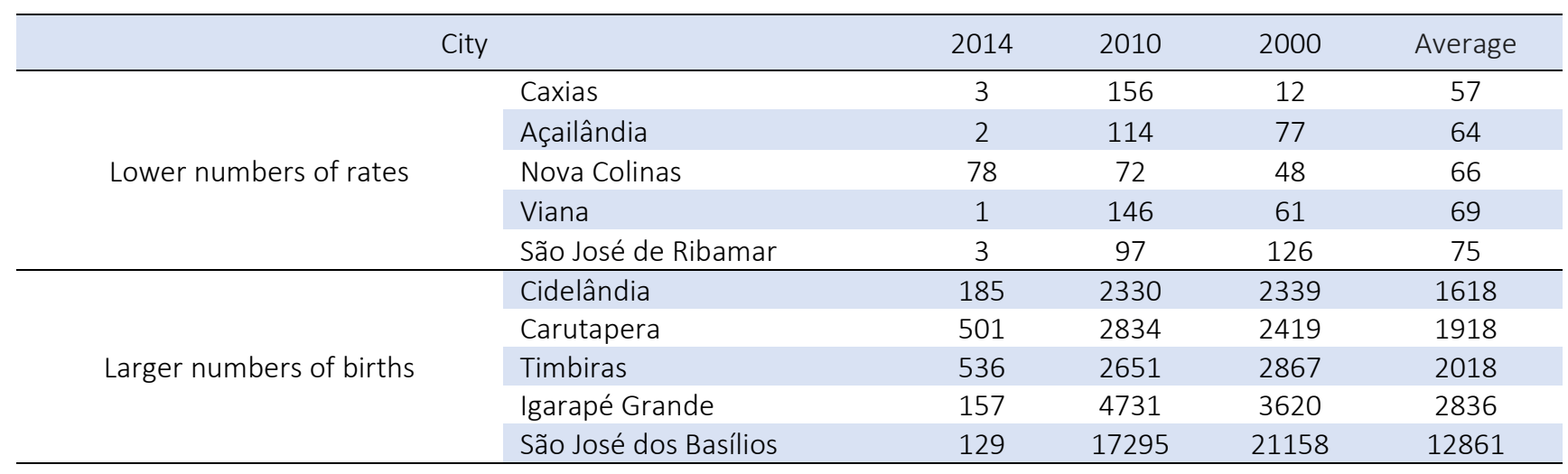

Caxias is a municipality located to the east of the state, on the border with Piaui state, near the capital Teresina, with a population of more than 155 thousand inhabitants. It has a GDP per capita of 9 thousand reais and HDI (Human Development Index) of 0.624 . Açailândia is located to the west of Maranhão, in the Tocantina region. It has a population of around 104 thousand people. It has a GDP per capita of almost 17 thousand reais and HDI of 0.672 .

The municipality of Nova Colinas is located in the southern region of the state. It has an environment of 5 thousand inhabitants. GDP per capita is almost 9 thousand reais and the $\mathrm{HDI}$ is 0.566 . Viana is located to the north of the state, in the Baixada Maranhense region.
It has 50 thousand inhabitants and a GDP per capita of 6 thousand reais and HDI of 0.618 . The city of São José de Ribamar is located in the metropolitan area of the capital São Luís, on the coast. It has more than 163 thousand inhabitants. It has a GDP per capita of 9 thousand reais and HDI of 0.708 (IBGE, 2014).

Cidelândia is located in Tocantina region, next to Açailândia. It has a population of more than 13 thousand people, with GDP per capita of 9 thousand reais and HDI of 0.6. Carutapera is to the west of the state, to the north, on the border with the state of Pará, with GDP per capita of 6 thousand reais and $\mathrm{HDI}$ of 0.574 . Timbiras is located in the center region to the east of the state. It has a population of 28 thousand people, with GDP 
per capita of 4 thousand reais and HDI of 0.537.

Igarapé Grande is in the center of Maranhão state. It has a population of 11 thousand people, GDP per capita of 6 thousand reais and HDI of 0.614. São José dos Basilios is in the coastal West region. With a population of more than 7 thousand people, with GDP per capita of 6 thousand reais and HDI of 0.557 (IBGE, 2014).

The cities with the highest number of births have the lowest HDI and GDP per capita lower than the ones that had the lowest number of births. Possibly the cities that have a higher income, are the ones that also have more birth control programs and access to education. The HDI of Brazil was 0.8 in 2005, on a scale of 0 to 1 , is that countries below 0.8 are considered to be of medium human development, being Maranhão among the five states with the lowest HDI, 0,65 (IBGE, 2014).

\section{CONCLUSION}

Maranhão is characterized by municipalities with less than 600 live births per year, with the lowest rates in the southern mesoregion

\section{REFERENCES}

Costa, J.M.B.S.; Frias, P.G. 2009. Avaliação da completitude das variáveis da Declaração de Nascido Vivo de residentes em Pernambuco, Brasil, 1996 a 2005. Caderno de Saúde Pública; 25(3):613-624.

D’orsi, E.; Carvalho, M.S. 1998. Perfil de nascimentos no Município do Rio de Janeiro: uma análise espacial. Caderno de Saúde Pública; 14:367-79.

IBGE. 2009. Indicadores sociodemográficos e de saúde no Brasil. IBGE, Coordenação de População e Indicadores Sociais. Rio de Janeiro. ISBN: 9788524040825 n 25.157p.

IBGE, 2014. Cidades. Instituto Brasileiro de Geografia e Estatística. Disponível em: http://cidades.ibge.gov.br/.

Jorge, M.H.P.M.; Laurenti, R.; Gotlieb, S.L.D. 2007. Análise da qualidade das estatísticas vitais brasileiras: a experiência de implantação do SIM e do SINASC. Ciência da saúde coletiva, vol.12, n.3.

Mello-Jorge, M.H.P.; Gotileb, S.L.D.; Soboll, M.L.M.S.; Almeida, M.F.; Latorre, M.R.D.O. 1993. Avaliação do Sistema de Informações sobre Nascidos Vivos e o uso de seus dados em epidemiologia e estatísticas de saúde. Revista de Saúde Pública; 27 Suppl:1-44.

Mello-Jorge, M.H.P.; Gotlieb, S.L.D.; Andrade, S.M. 1997. Análise dos registros de nascimentos vivos em localidade urbana no Sul do Brasil. Revista de Saúde Pública; 31:7889.

Mello-Jorge, M.H.P.; Gotlieb, S.L.D.; Oliveira, H. 1996, O Sistema de Informações sobre Nascidos Vivos: primeira avaliação dos dados brasileiros. Informativo de Epidemiologia do SUS; 2:15-48.

OMS: Organização Mundial da Saúde. Classificação Estatística Internacional de Doenças e Problemas relacionados à Saúde. 1995. 10a revisão. São Paulo, CBCD, v.1 e v. 2.

Rodrigues, C.S.; Magalhães-Junior, H.M.; Evangelista, P.A.; Ladeira, R.M.; Laudares, S. 1997. Perfil dos nascidos vivos no Município de Belo Horizonte, 1992-1994. Caderno de Saúde Pública; 13:53-7.

Romero, D.E.; Cunha, C.B. 2007. Avaliação da qualidade das variáveis epidemiológicas e 
demográficas do Sistema de Informações sobre Nascidos Vivos, 2002. Caderno de Saúde Pública; 23(3):701-714.

Santa-Helena, E.T.; Wisbeck, J. 1998. Implantação do SINASC e perfil dos nascidos vivos de Blumenau, 1994-1997. Informativo de Epidemiologia do SUS; 3:35-42.

Silva, R.I; Theme-Filha, M.M.; Noronha, C.P. 1997. Sistema de Informações sobre Nascidos Vivos na cidade do Rio de Janeiro 1993/1996. Informativo de Epidemiologia do SUS; 2:3448.

Theme-Filha, M.M.; Gama, S.G.N.; Cunha, C.B.; Leal, M.C. 2004. Confiabilidade do Sistema de Informações sobre Nascidos Vivos Hospitalares no Município do Rio de Janeiro, 1999-2001. Caderno de Saúde Pública; 20(Supl. 1): S83-91. 